\title{
The Effect of e-portfolio on Biological Concepts Understanding and Responses of Students with Different Academic Achievement Levels
}

\author{
Marheny Lukitasari \\ Universitas PGRI Madiun, Indonesia, marheny@unipma.ac.id \\ Rusdi Hasan \\ Universitas Muhammadiyah Bengkulu, Indonesia,rusdihasan@umb.ac.id \\ Akhmad Sukri \\ Universitas Pendidikan Mandalika, Indonesia,akhmadsukri@ikipmataram.ac.id
}

The purpose of this research was to determine (1) the effect of e-portfolio use on understanding Biology concepts of students at different academic levels and (2) knowing student responses in the use of e-portfolios. This research is experimental research using a one-shot case study design. Data on understanding students' concepts were collected through the results of learning tests, while student response data were collected through questionnaires. The data analysis used parametric statistics through descriptive statistical analysis and variants. The results of the study show that (1) there are differences in understanding the Biology concept of students at different academic levels $(\mathrm{p}<0.05)$, namely understanding concepts at high academic levels is better than at low academic levels ; (2) all students at the level of high and low academic abilities show a positive response to the use of e-portfolio which includes three aspects, namely (a) the benefits of using e-portfolio, (b) completion of tasks, and (c) student attitudes and interests.

Keywords: e-portfolio, concept understanding, student response, biological concepts, academic achievement

\section{INTRODUCTION}

The changes of the world due to the influence and development of internet-based technology are a concern, including in the education world, resulting in many approaches to be used in various forms (Al-Adwan et al, 2013). The use of the internet in the form of e-learning, as well as more and more learning resources, is utilized to support learning activities and skills in the 21 st century. One form of technology use in learning activities is changing the collection of task results and student learning activities from portfolios to electronic portfolios (e-portfolios). Changes and trends in

Citation: Lukitasari, M., Hasan, R., \& Sukri, A. (2020). The Effect of e-portfolio on Biological Concepts Understanding and Responses of Students with Different Academic Achievement Levels. International Journal of Instruction, 13(1), 685-694. https://doi.org/10.29333/iji.2020.13144a 
the use of e-portfolios in higher education have become increasingly popular over the past ten years (Reese \& Levy, 2009), which have also been able to activate students in studying (Gorbunovs et al, 2013). Basically, the use of many types of tasks that are structured and then documented is often carried out by the lecturer with the aim of improving the ability of students to study material, including as an evaluation tool (Pantiwati, 2010).

The definition of e-portfolio in many perspectives illustrates that this facility is able to accommodate all the results of learning activities based on the assignments given by lecturers and prepared by students. The task collection in the e-portfolio will describe the ability of students during the learning process from time to time (Chau \& Cheng, 2010), thus facilitating the evaluation process. The e-portfolio is also a new platform that allows students to collect learning outcomes, organize them as well as present them in digital form that can be used from time to time in accordance with the objectives to be implemented (Amaya et al, 2013).

Many studies have revealed that portfolios are able to describe students' knowledge and learning experiences (Gamiz-Sanchez et al, 2016). The existence of e-portfolios as a form of description between processes and products through activities of selection, collection, as well as reflection on the learning outcomes that have been implemented, can explain student learning experiences (Keegan, 2009; Chang, 2009). In student learning independence, e-portfolios are also able to be a means to evaluate their learning abilities by looking at learning content, schedules, revising and even discussing them online (Chau, 2007). The use of e-portfolios seems to be a tool that can be used as an evaluation while improving the learning process in many European countries (Klenowski, 2006; Park, 2009; Ahn, 2004).

The implementation of the e-portfolio does have the potential to support the learning process. But the problem still needs some consideration when an institution will use the results of the development of the technology. In addition to readiness in terms of supporting facilities, it is very necessary to consider the conditions and competencies of users (Reese \& Levy, 2009), namely lecturers and students. The question that arises is related to the use of e-portfolios such as how effective the facilities are in developing students' abilities, how students respond as users, how the motivation and interests of users when e-portfolios are applied are important points to consider. The results of previous studies conducted by Lukitasari et al (2018) revealed that the implementation of e-portfolios in project based learning can improve students' high-order thinking skills, but it is not yet known whether the implementation of e-portfolios can be done at different academic levels. This study will reveal the results of the implementation of eportfolios towards student's concepts understanding and the impact of their implementation on students with different academic levels.

\section{METHOD}

This research is an experimental study using one-shot case study (Flannelly et al, 2018) The treatment of e-portfolio learning was carried out at the Cell Biology course consisting of 40 students distinguished by their academic levels in the high and low 
categories. Research activities were conducted at the Universitas PGRI Madiun for one semester in the 2017/2018 academic year. The difference in academic level is determined by the attainment of the student achievement index (IP) value, if the IP $\geq$ 3.00 is classified into a high academic level and IP $<3.00$ is classified into a low academic level. Based on the category of the pretest index value, 11 students had high academic abilities and 29 students with low academic abilities.

\section{Research Procedure}

Research activities through one-shot case study are carried out through three stages, namely: (1) Preparation phase: the lecturer conveys knowledge about e-portfolio as well as demonstrate in using the facility. It was also explained that the components of the task to be worked on included student worksheets (LKM), papers (Mkl) and learning journals (LJ), which could be done either independently or in groups. (2) The implementation phase: learning using e-portfolios was conducted at the Cell Biology course covering seven material after the midterm. For paper and work assignments, LKMs are conducted in groups, while for LJ they are done individually for each lecture session. In detail, the implementation of the task is as follows.

Table 1

Lecture Material and Types of Assignments

\begin{tabular}{lll}
\hline No & Material & Types of assignments \\
\hline 1 & $\begin{array}{l}\text { Structure and function of mitochondria and chloroplasts } \\
2\end{array}$ & $\begin{array}{l}\text { Nucleus structure and function, cell genetic material and } \\
\text { DNA replication }\end{array}$ \\
& $\begin{array}{l}\text { The structure and function of ribosome and the mechanism } \\
\text { of protein synthesis }\end{array}$ & LKM, LJ \\
4 & Cell cycle and the mechanism of mitosis and meiosis & LKM, LJ \\
5 & Interactions and communication between cells & Mkl, LJ \\
6 & Apoptosis, necrosis, and aging in cells & LKM, LJ \\
7 & Stem cell and cell regeneration & LKM, LJ \\
\hline
\end{tabular}

(3) The evaluation phase, all documentation produced during the learning activities is uploaded on the web e-portfolio in stages and then is assessed by self, friends, and lecturers.

\section{Data and Data Analysis}

Data on understanding students' concepts are collected through learning outcomes tests in the form of essay questions totaling 20 questions and their validity and reliability have been tested. Each question has a rating range from 0-100. Data on student responses to the implementation of e-portfolios was collected using a questionnaire containing 20 question items modified based on Kwok (2011) covering three criteria namely (a) the benefits of using e-portfolio, (b) completion of tasks, and (c) student attitudes and interests. This adopted questionnaire has been translated into the foreign language.

Scores on questionnaires are in the range of $1-5$, with score criteria $1=$ strongly disagree, $2=$ disagree, $3=$ quite agree, $4=$ agree, and $5=$ strongly agree to positive 
questions, while negative questions apply otherwise. The results of the score (S) are then converted with the following conditions: $4<\mathrm{S} \leq 5$ (very positive), $3<\mathrm{S} \leq 4$ (positive), 2 $<\mathrm{S} \leq 3$ (quite positive), $1<\mathrm{S} \leq 2$ (less positive), and $\mathrm{S} \leq 1$ (not positive). Data on students 'conceptual understanding were analyzed using analysis of variance to determine differences in understanding students' concepts at different academic levels. While student response data were analyzed using descriptive statistics in the form of student response rates per item question.

\section{FINDINGS}

\section{Effect of e-Portfolio on Understanding Student Concepts}

The homogeneity test results at each academic level are shown in Table 2.

Table 2

The Test of the Homogeneity of Understanding Concepts of Students at Different Academic Levels

\begin{tabular}{lllll}
\hline \multicolumn{1}{c}{ Academic Ability } & Mean & SD & F & Sig \\
\hline Height & 75.36 & 7.54 & 0.77 & 0.39 \\
Low & 62.06 & 9.16 & 0.77 & 0.39 \\
\hline
\end{tabular}

Table 2 that shows the significance of high and low academic levels is greater than 0.05 , which is 0.39 , so it has a homogeneous variance. After conducting the homogeneity test, the analysis continued with the F test using analysis of variance (ANOVA) as shown in Table 3.

Table 3

Results of Analysis of Variance in Understanding Students' Concepts at Different Academic Levels

\begin{tabular}{llllll}
\hline \multicolumn{1}{c}{ Source } & $\begin{array}{l}\text { Type III Sum of } \\
\text { Squares }\end{array}$ & df & Mean Square & F & Sig. \\
\hline Corrected Model & $1170.910^{\mathrm{a}}$ & 2 & 585.455 & 7.755 & .003 \\
Intercept & 1823.114 & 1 & 1823.114 & 24.150 & .000 \\
Pretest & 16.568 & 1 & 16.568 & .219 & .644 \\
Level of Academic & 853.862 & 1 & 853.862 & 11.311 & .003 \\
Error & 1811.797 & 24 & 75.492 & & \\
Total & 125920.470 & 27 & & & \\
Corrected Total & 2982.707 & 26 & & & \\
\hline
\end{tabular}

a. R Squared $=.393($ Adjusted R Squared $=.342)$

Table 3 shows there are differences in understanding the biological concepts of students at different academic levels, with a significance value of 0.003 . Table 3 also shows that understanding the biological concepts of students at high academic levels is better than at low academic levels. This result is reinforced by the average value of students' conceptual understanding, namely 75.36 and 62.06 (Table 2). 


\section{Student Response to the Implementation of E-Portfolio}

The results of student responses to the implementation of e-portfolios are described as follows:

Differences in the benefits of using e-portfolios for students with different academic levels

The results of the questionnaire analysis of student responses to the benefits of using eportfolios in lectures are shown in Table 4.

Table 4

Benefits of Using E-Portfolios in Lectures at Different Academic Levels

\begin{tabular}{lll}
\hline Questions & $\begin{array}{l}\text { Average group with } \\
\text { high academic ability } \\
(\mathrm{H})\end{array}$ & $\begin{array}{l}\text { Average group with a } \\
\text { low academic ability } \\
(\mathrm{L})\end{array}$ \\
\hline $\begin{array}{l}\text { Tasks uploaded on relevant web portfolios } \\
\text { with what I learned }\end{array}$ & 3.45 & 3.88 \\
\hline $\begin{array}{l}\text { E-portfolio assignments can help me make } \\
\text { an assessment of my own abilities. }\end{array}$ & 4.00 & 3.69 \\
\hline E-Portfolio allows me to utilize time better. & 3.64 & 3.69 \\
\hline E-Portfolios can eliminate misconceptions. & 3.09 & 3.31 \\
\hline $\begin{array}{l}\text { Before making an assessment, I made a } \\
\text { revision of the e-portfolio assignment. }\end{array}$ & 3.64 & 3.44 \\
\hline $\begin{array}{l}\text { I learned from the feedback given in the } \\
\text { portfolio }\end{array}$ & 3.64 & 3.81 \\
\hline $\begin{array}{l}\text { E-portfolio assignments can help me to } \\
\text { study Cell Biology. }\end{array}$ & 4.09 & 4.06 \\
\hline Average & 3.65 & 3.70 \\
\hline
\end{tabular}

Table 4 shows the two student groups gave a positive response to the questionnaire questions for the benefits of using e-portfolios to assist the learning process. The average score for all question items in the group of high and low academic students are 3.65 and 3.70 and are in the category of agree. This means that all students agree to implement e-portfolios useful in helping the learning process.

Differences in task completion through e-portfolios for students with different academic abilities

The results of student responses to the completion of assignments in e-portfolios for different academic abilities are shown in Table 5. 
Table 5

Results of Student Responses to Completion of Tasks in E-Portfolio on Academic Ability is Different

\begin{tabular}{lll}
\multicolumn{1}{c}{ Questions } & $\begin{array}{l}\text { Average groups } \\
\text { with high } \\
\text { academic abilities } \\
(\mathrm{H})\end{array}$ & $\begin{array}{l}\text { Average group with } \\
\text { a low academic } \\
\text { ability (L) }\end{array}$ \\
\hline $\begin{array}{l}\text { I like the portfolios at that time because it } \\
\text { comfort me. }\end{array}$ & 3.55 & 3.44 \\
\hline $\begin{array}{l}\text { I made a plan about when and how to do the e- } \\
\text { portfolio task. }\end{array}$ & 3.55 & 3.50 \\
\hline $\begin{array}{l}\text { I managed to follow the plan. } \\
\begin{array}{l}\text { I completed the e-portfolio task as quickly as } \\
\text { when it was learned in class. }\end{array}\end{array}$ & 3.55 & 3.44 \\
\hline $\begin{array}{l}\text { I revised the material before trying the topic that } \\
\text { will be uploaded in the web e-portfolio. }\end{array}$ & 3.73 & 3.50 \\
\hline $\begin{array}{l}\text { I finished the e-portfolio task before time was up. } \\
\text { I will do the assignments in the e-portfolio if } \\
\text { there is a score given. }\end{array}$ & 2.64 & 4.06 \\
\hline \multicolumn{1}{c}{ Average } & 3.35 & 2.44 \\
\hline
\end{tabular}

Table 5 shows the two student groups gave a positive response to the questionnaire questions for completing assignments in e-portfolio in helping the learning process. The mean score for all question items at the high and low academic levels is 3.35 and 3.34 respectively and entered into the agreed category.

Differences in attitudes and interests in the use of e-portfolios for students with different academic abilities

The results of differences in attitude analysis and interest in the use of e-portfolios in students with different academic abilities are shown in Table 6. 
Table 6

Student Attitudes and Interests in the Use of E-Portfolios at Different Academic Abilities

\begin{tabular}{lll}
\multicolumn{1}{c}{ Questions } & $\begin{array}{l}\text { Average groups } \\
\text { with high } \\
\text { academic abilities } \\
\text { (H) }\end{array}$ & $\begin{array}{l}\text { Average group } \\
\text { with a low } \\
\text { academic ability } \\
\text { (L) }\end{array}$ \\
\hline $\begin{array}{l}\text { The electronic portfolio is an efficient way to } \\
\text { support the learning process. }\end{array}$ & 3.42 & 3.50 \\
\hline $\begin{array}{l}\text { I feel valued when giving opinions or comments on } \\
\text { the web e-portfolio }\end{array}$ & 3.75 & 3.25 \\
\hline $\begin{array}{l}\text { Task E-portfolio is just homework for me. } \\
\begin{array}{l}\text { I feel troubled when I have to upload material that I } \\
\text { have compiled. }\end{array}\end{array}$ & 3.67 & 2.38 \\
\hline $\begin{array}{l}\text { The many and complicated Biology Cell materials } \\
\text { are helped by the existence of a web e-portfolio. }\end{array}$ & 4.75 & 2.31 \\
\hline $\begin{array}{l}\text { I still experience confusion in finding learning } \\
\text { resources through the internet. }\end{array}$ & 3.75 & 2.44 \\
\hline \multicolumn{1}{c}{ Average } & 3.81 & 2.81 \\
\hline
\end{tabular}

Table 6 shows that the two student groups showed different attitudes towards the interest in using e-portfolios in the learning process. For students with high academic abilities, they show the attitude of agree (3.81), while for students with low academic abilities, they agree enough (2.81). But overall, students are interested in using e-portfolios in learning.

\section{DISCUSSION}

The results of the study in terms of the response to the use of e-portfolios generally indicate that the facility helps students in supporting their learning activities. The average difficulty encountered is in terms of technical use, which indicates that the existence of e-portfolio still requires habituation in terms of its use. An interesting finding in this study was that students claimed to experience confusion in finding learning resources through the internet $(\mathrm{H}=3.75, \mathrm{~L}=2.00)$. This is in accordance with Shepherd \& Bolliger (2011) research that in some parts of the e-portfolio format tends to make students confused. But on the other hand, these conditions actually make the interaction between lecturers and students make it so that discussions develop their thinking ability.

The e-portfolio facilities that are relatively recently used also provide new experiences for students, especially in the use of technology as an important component to support learning activities. The results of this study reveal that the implementation of eportfolios can help improve the understanding of cell biology concepts because there is a tendency that the students observe and repeat the material without limited time and place. Students have the opportunity to review and revise all the tasks that have been done and also discuss them. These results support the results of the D'Angelo \& Wright (2012) study which found that the implementation of e-portfolios had a positive effect 
on students' perceptions of learning, and also could improve the science generic abilities of the student (Ramlawati et al, 2014), increasing participation, motivation and student self-learning ability (Gámiz-Sánchez et al, 2016) and can improve student knowledge sharing (Chang et al, 2018). In addition, these facilities can simultaneously improve student self-regulated learning which includes self-regulated learning processes, intrinsic goal orientation, metacognitive self-regulation, effort regulation, elaboration, rehearsal, and critical thinking (Nguyen \& Ikeda, 2015), which of course impact on students' understanding of Cell Biology material.

Although the explanation of the potential of e-portfolios is a tool that is able to help students to improve understanding of the concept, in this case, it is apparent in students with high academic abilities. This means that understanding the concept of students with high academic abilities from the start shows better test results. And these conditions become the initial capital of high academic ability students in understanding the material even though there is a possibility that they do not understand the benefits and uses of eportfolios. However, the use of e-portfolios that make it easier for students to review the results of their work becomes one of the advantages that appear in the learning activities. Indirectly when students examine the results of their work at the same time they repeat the material that has been discussed. On the other hand, as a means of evaluation, the lecturers also experience the ease of monitoring the progress of their student learning. This study supports the results of previous studies (Kilbane and Milman, 2017; Khodashenas and Rakhshi, 2017) that the implementation of e-portfolios is not only beneficial for students but also for lecturers, especially in terms of habitual use of technology. Lecturers have a better understanding of the conditions of student learning through reflective activities and reciprocal interactions both online and offline. In general, the e-portfolio model can be adopted to be implemented in learning to improve students' conceptual understanding.

\section{CONCLUSION}

Based on the results of the analysis of understanding the concepts and responses of students through the implementation of e-portfolio, it was concluded that (a) the implementation of e-portfolio had an impact on the understanding of students' Biology concepts and (b) the implementation of e-portfolio was responded positively by students at both high and low academic levels. Therefore, the implementation of e-portfolio in learning can be done for all academic levels of students, to change the traditional learning paradigm towards technology-based learning. E-portfolio has not fully supported students in the learning process even though qualitatively in terms of use they experience attraction because it is a relatively new tool. However, further research is still needed regarding the effectiveness of using e-portfolios in terms of developing individual abilities and the motivation of students to become independent learners. 


\section{REFERENCES}

Ahn, J. (2004). Electronic portfolios: Blending technology, accountability \& assessment. The Journal, 31(9), 12-18.

Al-Adwan, A., Al-Adwan, A., \& Smedley, J. (2013). Exploring students acceptance of e-learning using Technology Acceptance Model in Jordanian universities. International Journal of Education and Development using ICT, 9(2), 4-18.

Amaya, P., Agudo, J. E., Sánchez, H., Rico, M., \& Hernández-Linares, R. (2013). Educational e-portfolios: Uses and Tools. Proc. - Soc. and Beha. Sci., 93, 1169-1173

Chau, J. (2007). A developer's challenges on an e-portfolio journey. ICT: Providing Choices for Learners and Learning, 145-148.

Chau, J., \& Cheng, G. (2010). Towards understanding the potential of e-portfolios for independent learning: A qualitative study. Aus. J. of Edu. Technology, 26(7), 932-950.

Chang, C. C. (2009). Self-evaluated effects of web-based portfolio assessment system for various student motivation levels. J. of Edu. Computing Research, 41(4), 391-405.

Chang, C. C., Chou, P. N., \& Liang, C. (2018). Using ePortfolio-based learning approach to facilitate knowledge sharing and creation of college students. Australasian Journal of Educational Technology, 34(1), 30-41.

D’Angelo, D., Finnin, C., \& Wright, J. (2012). The Impact of ePortfolios on Students' Learning. International Journal of Business and Social Research, 2(4), 25-34.

Flannelly, K. J., Flannelly, L. T., \& Jankowski, K. R. (2018). Threats to the internal validity of experimental and quasi-experimental research in healthcare. Journal of Health Care Chaplaincy, 24(3), 107-130.

Gámiz-Sánchez, V-M., Gallego-Arrufat, M-J., \& Crisol-Moya, E. (2016). Impact of electronic portfolios on prospective teachers' participation, motivation and autonomous learning. Journal of Information Technology Education Research, 15, 517-533.

Gorbunovs, A., Kapenieks, A., \& Kudina, I. (2013). Competence development in a combined assessment and collaborative e-portfolio information system. Procedia Computer Science, 26, 79-100.

Keegan, H. (2009). Formal to informal-education to industry; Easing the transition through social media. Online Educa Berlin.

Khodashenas, M. R., \& Rakhshi, F. (2017). The effect of electronic portfolio assessment on the writing performance of Iranian EFL learners. International Journal of Research in English Education, 2(3), 67-77.

Kilbane, C. R., \& Milman, N. B. (2017). Examining the impact of the creation of digital portfolios by high school teachers and their students on teaching and learning. International Journal of ePortfolio, 7(1), 101-109. 
Klenowski, V., Askew, S., \& Carnell, E. (2006). Portfolios for learning, assessment and professional development in higher education. Asse. \& Eval. in H. Edu, 31(3), 267-286.

Kwok, L. (2011). College students' participation in e-portfolio learning in relation to academic ability and motivation. E. J. of Foreign Language Teaching, 8(2), 246-267.

Lukitasari, M., Handhika, J., \& Murtafiah, W. (2018). Higher order thinking skills: using e-portfolio in project-based learning. J. of Phys.: Conference Series, 983, 012047.

Nguyen, L. T., \& Ikeda, M. (2015). The effects of ePortfolio-based learning model on student self-regulated learning. Active Learning in Higher Education, 16(3), 197-209.

Pantiwati, Y. 2010. Pengaruh Jenis Asessment Biologi dalam Pembelajaran Kooperatif TPS (Think Pair Share) terhadap Kemampuan Kognitif, Berpikir Kritis, dan Kesadaran Metakognitif Siswa SMA di Kota Malang (Unpublished doctoral dissertation). Universitas Negeri Malang, Indonesia.

Park, S. Y. (2009). An analysis of the technology acceptance model in understanding university students' behavioral intention to use e-learning. Edu Tec \& So,12(3),150-162.

Ramlawati, Liliasari, Martoprawiro, Muhamad A., and Wulan, A, R. (2014). The Effect of electronic portfolio assessment model to increase of students' generic science skill in practical inorganic chemistry. Journal of Education and Learning, 8(3), 179-186.

Reese, M., \& Levy, R. (2009). Assessing the future: E-portfolio trends, uses, and options in higher education. EDUCAUSE Research Bulletin, 2009(4), 1-12

Shepherd, C. E., \& Bolliger, D. U. (2011). The effects of electronic portfolio tools on online students' perceived support and cognitive load. The Internet and Higher Education, 14(3), 142-149. 